\title{
Quo vadis lactoferrin?
}

\author{
Hans J. Vogel $\cdot$ Antimo Cutone $\cdot$ Maria S. Lepanto $\cdot$ Luigi Rosa $\cdot$ \\ Piera Valenti
}

Published online: 17 May 2018

(C) Springer Science+Business Media, LLC, part of Springer Nature 2018

The XIIIth International Conference on Lactoferrin, Structure Function and Applications was held in Rome, from November 5-10, 2017. This meeting followed on the heels of the successful XIIth, XIth and Xth Lactoferrin meetings, which were held in Nagoya in 2015, in Rome in 2013, and in Mazatlan in 2011, respectively. The well-attended 2017 meeting was held in the conference centre of a hotel that was located very near to the Villa Borghese. During breaks in the program, the meeting participants could draw inspiration from their walks in the extensive park surrounding the Villa or from brief trips to the famous historic sites in the centre of Rome. During one of these trips, it is alleged, that the mythical Roman Shewolf, who according to ancient legend nursed the abandoned infants Romulus and Remus back to health, appeared in a vision of some members of the lactoferrin community. During this unexpected and

H. J. Vogel $(\bowtie)$

Department of Biological Sciences, University of Calgary, Calgary, AB, Canada

e-mail: vogel@ucalgary.ca

\section{A. Cutone}

Department of Biosciences and Territory, University of Molise, Pesche, Italy

M. S. Lepanto · L. Rosa · P. Valenti ( $\square)$

Department of Public Health and Infectious Diseases,

Sapienza University, Rome, Italy

e-mail: piera.valenti@uniroma1.it surreal encounter they asked her: "Where are you going?" and the She-wolf replied: "I am going to Rome, to participate for the second time in the Lactoferrin Conference. After I provided the milk that was loaded with lactoferrin, the two twins grew up extremely healthy and strong, so I can now go back to Rome to tell my story and to learn about all the other new findings regarding lactoferrin" (see Fig. 1). Indeed there was a lot to be learned about new lactoferrin applications and novel insights into the mechanism of action of this protein during the 2017 meeting and some of these contributions are highlighted in this Special Issue of the BioMetals journal.

For the first time the opening session of the meeting was focused entirely on descriptions and discussions of the procedures that are applied to purify the protein, as well as the different methods that can be used to evaluate the quality of highly purified lactoferrin. Another major aim of the XIIIth Conference was to try to define the impact of different degrees of iron saturation, the protein purity and integrity, the presence of contaminants and the stability of the protein and its derived bioactive peptides, on the many beneficial functions of lactoferrin. Such data will greatly contribute to increased use of lactoferrin for potential therapeutic applications or for promoting human health and wellness.

It is well known that human lactoferrin (hLf), an iron-binding multifunctional cationic glycoprotein with a molecular weight of about $80 \mathrm{kDa}$, that is 


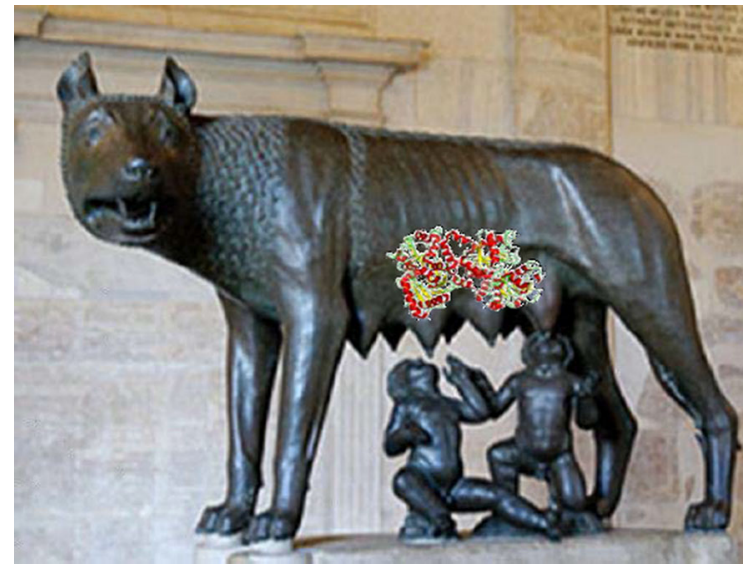

Fig. 1 The mythical She-wolf suckling the twins Romulus and Remus with milk loaded with lactoferrin

secreted by exocrine glands and by neutrophils, is a key element of the human host defense (Vogel 2012; Alexander et al. 2012). The protein is also found in high concentrations in milk produced by all lactating species, and is especially abundant in the colostrum. Clearly milk, and milk proteins that are present in copious amounts, such as lactoferrin, play a major role in nutrition and providing initial immune protection to newborns. However the host defense roles of lactoferrin also extend to much later in life. It is difficult to obtain large quantities of the hLf protein for research purposes, although the protein can be made recombinantly (Ward et al. 1995). However, fortunately the dairy industry has succeeded in purifying large quantities of bovine lactoferrin (bLf) from cows milk, and many researchers feel that this protein shares many of the beneficial properties of hLf. Consequently most of the in vitro and in vivo studies that were reported at the meeting had been performed with bLf, a product that is generally recognized as safe by the Food and Drug Administration. Indeed, hLf and bLf have high sequence homology and overlapping biological functions, and depending on their iron binding status they can both inhibit bacterial growth and biofilm formation, while, independent from their iron chelation properties, they can also block bacterial adhesion and entry into cells (Valenti and Antonini 2005; León-Sicairos et al. 2014; Kieckens et al. 2018).

BLf also exerts an anti-inflammatory activity by decreasing the levels of the cytokine interleukin-6 (IL-6), which in turn leads to up-regulation of the biosynthesis of ferroportin (Fpn), membrane-bound ceruloplasmin $(\mathrm{Cp})$ and transferrin receptor 1 (TfR1), as well as down-regulating the production of ferritin (Ftn), all pivotal actors in iron metabolism and inflammatory homeostasis (Cutone et al. 2017; Bonaccorsi di Patti et al. 2018). Consequently, administration of bLf can inhibit intracellular iron overload, an unsafe condition enhancing host susceptibility to infections, while simultaneously treating anemia of inflammation, thereby re-establishing normal iron metabolism and inflammatory homeostasis (Rosa et al. 2017).

During the meeting it was extensively discussed that the physico-chemical heterogeneity, as well as the purity and the presence of degradation fragments in different commercial bLf preparations can influence its effectiveness (Rosa et al. 2018; Wakabayashi et al. 2018). Also the degree of $\mathrm{Fe}(\mathrm{III})$ saturation and the ability of the protein to chelate other metal ions such as $\mathrm{Al}(\mathrm{III}), \mathrm{Cu}(\mathrm{II}), \mathrm{Mg}(\mathrm{II}), \mathrm{Mn}(\mathrm{II})$, and $\mathrm{Zn}$ (II) can influence the bacteriostatic activity of commercial bLf preparations, while the ability to sequester $\mathrm{Ca}$ (II) can affect the lipopolysaccharide (LPS)-dependent bactericidal activity. In addition, proper glycosylation of the known N-glycosylation sites of the protein (Karav et al. 2017) has been associated with increased resistance to proteolysis, while the presence of typical biomolecular contaminants, such as LPS, angiogenin and lactoperoxidase also influences its efficacy (Rosa et al. 2018; Wakabayashi et al. 2018). Furthermore, the characteristic ability of Lf to enter inside the nucleus of the cell affects its anti-inflammatory activity (Rosa et al. 2018). Moreover, in this Special Issue, Parrón et al. (2018) describe differences in Lfs obtained from different species (ovine, swine and camel as well as the human recombinant form) with regards to their heat-susceptibility thereby directly influencing the anti-rotaviral activity of the proteins. Encouragingly, and different from pasteurization, it was shown that high hydrostatic pressure treatment does not cause a significant decrease in this neutralizing activity of Lfs (Parrón et al. 2018). Also Wakabayashi et al. (2018) recommend that in order to achieve reliable and reproducible results, researchers should use lactoferrin of a high-grade of purity and make sure that the protein has been carefully stored; researchers should also indicate the manufacturers' names and specifications in their scientific publications. 
The biological activities of Lf-derived peptides form another expanding area of Lf research. Various Lf-derived peptides are well known to act as potent antibacterial, antiviral, antiparasitic, anti-inflammatory and anticancer agents (Gifford et al. 2005; van der Kraan et al. 2006; Bolscher et al. 2009; Arias et al. 2017). Moreover, specific chemical modifications of lactoferricin, a short cationic peptide composed of twenty-five residues that is derived from the basic $\mathrm{N}$-terminal region of bLf, can lead to optimization of its biological and therapeutic applications (Hao et al. 2018).

Recently, multiple biological functions of Lf have been postulated to be mediated by binding of the protein to an $\mathrm{Lf}$ receptor (LfR). The LfR plays an important role in the absorption of Lf and Lf-bound iron by intestinal epithelial cells. In the study of Jiang and Lonnerdal (2018), cloning and the subsequent characterization of the human LfR gene promoter were achieved, using human enterocyte Caco- 2 cells as a model system. The transcription start site of the human LfR gene and some regulatory core elements for the transcriptional activator $\mathrm{Sp} 1$ could be successfully identified in this work (Jiang and Lonnerdal 2018). In addition, the role of hLf in the biliary epithelium was studied by other investigators; specifically Mancinelli et al. (2018) evaluated the expression of $\mathrm{Lf}$ and its receptors in human and murine cholangiocytes and their effect on proliferation. The results obtained by these researchers show that mouse and human cholangiocytes express Lf, LfR and a low specificity receptor intelectin-1 (ITLN1). Furthermore, the in vitro addition of bLf has a proliferative effect on the human cholangiocyte cell line, thus supporting the idea of a proliferative role for Lf in the biliary epithelium, which could be relevant in human cholangiopathies (Mancinelli et al. 2018).

Moreover, the pathogenicity of some important Gram-negative bacteria, that reside exclusively in the upper respiratory or the genitourinary tract of their mammalian hosts, rely on surface receptors that specifically bind Lf as a source of iron for growth (Chan et al. 2018). The study by Chan et al. (2018) focused on the bacterial LfRs, determining their prevalence in pathogenic bacteria and commensal Neisseria strains as compared to other surface antigens that could potentially be targeted for vaccines.

BLf has also been shown to be involved in the regulation of various intracellular pathways. As a matter of fact, bLF promotes expression of the gene for the uncoupling protein 1 (UCP1) in brown adipocytes through the cAMP-PKA signaling pathway. This process takes place via the LfR, and ultimately leads to increased energy expenditure in adipocytes (Nakamura et al. 2018). Moreover, in rat models, apo-recombinant human Lf (apo-rhLf), but not holo-rhLf, have been found to induce the translocation of nuclear factor-erythroid 2-related factor 2 (Nrf2) from the cytoplasm to the nucleus, an effect that is probably related to its capacity to induce the biosynthesis of erythropoietin (Zakharova et al. 2018). This regulatory pathway seems to be related to the protective role exerted by Lf in severe neurological disorders, such as Parkinson's disease and multiple sclerosis, as well as to its capacity to mitigate some of the severe symptoms (Zakharova et al. 2018).

To date, several clinical trials have already confirmed many of the results obtained with animal models for different bLf functions involved in human health and wellness. In this regard, a novel topical application of bLf was presented at the XIIIth lactoferrin conference, where the efficacy of bLf for promoting wound repair in subjects suffering from Bisphosphonate-Related Osteonecrosis of the Jaws was evaluated (Calvani et al. 2018). After surgical treatment of the osteonecrosis site, topical applications of bLf led to wound healing in a significantly shorter time (1-2 weeks), when compared to the classical medical treatment ( 2 or 3 months) (Calvani et al. 2018).

As can be seen from this selection of papers that were presented at the XIIIth Lactoferrin Conference in Rome in 2017, interest in Lf biology and applications is widening. In addition to new discoveries concerning the multiple functions of Lf, researchers are now paying closer attention to Lf quality control as an important parameter to ensure the effectiveness and reproducibility of their results both for in vitro and in vivo studies. It will be interesting to see if the current trend towards larger numbers of in vivo applications of $\mathrm{Lf}$ and its related peptides will continue. We will all certainly learn a lot more about "where lactoferrin is going" by participating in the XIVth Lactoferrin Conference, which will be held in late 2019, in the vicinity of Lima, Peru. 


\section{References}

Alexander DB, Iigo M, Yamauchi K, Suzui M, Tsuda H (2012) Lactoferrin: an alternative view of its role in human biological fluids. Biochem Cell Biol 90:279-306. https://doi. org/10.1139/o2012-013

Arias M, Hilchie AL, Haney EF, Bolscher JG, Hyndman ME, Hancock RE, Vogel HJ (2017) Anticancer activities of bovine and human lactoferricin-derived peptides. Biochem Cell Biol 95:91-98. https://doi.org/10.1139/bcb-20160175

Bolscher JG, Adão R, Nazmi K, van den Keybus PA, van't Hof W W, Nieuw Amerongen AV, Bastos M, Veerman AC (2009) Bactericidal activity of LFchimera is stronger and less sensitive to ionic strength than its constituent lactoferricin and lactoferramin peptides. Biochemie 91:123-132. https://doi.org/10.1016/j.biochi.2008.05.019

Bonaccorsi di Patti MC, Cutone A, Polticelli F, Rosa L, Lepanto MS, Valenti P, Musci G (2018) The ferroportin-ceruloplasmin system and the mammalian iron homeostasis machine: regulatory pathways and the role of lactoferrin. Biometals. https://doi.org/10.1007/s10534-018-0087-5

Calvani F, Cutone A, Lepanto MS, Rosa L, Valentini V, Valenti $\mathrm{P}$ (2018) Efficacy of bovine lactoferrin in the post-surgical treatment of patients suffering from bisphosphonate-related osteonecrosis of the jaws: an open-label study. Biometals. https://doi.org/10.1007/s10534-018-0081-y

Chan C, Andisi VF, Ng D, Ostan N, Yunker WK, Schryvers AB (2018) Are lactoferrin receptors in Gram-negative bacteria viable vaccine targets? Biometals. https://doi.org/10.1007/ s10534-018-0105-7

Cutone A, Rosa L, Lepanto MS, Scotti MJ, Berlutti F, Bonaccorsi di Patti MC, Musci G, Valenti P (2017) Lactoferrin efficiently counteracts the inflammation-induced changes of the iron homeostasis system in macrophages. Front Immunol 8:705. https://doi.org/10.3389/fimmu.2017. 00705

Gifford JL, Hunter HN, Vogel HJ (2005) Lactoferricin: a lactoferrin-derived peptide with antimicrobial, antiviral and immunological properties. Cell Mol Life Sci 62:2588-2598. https://doi.org/10.1007/s00018-005-5373$\mathrm{Z}$

Hao Y, Yang N, Teng D, Wang X, Mao R, Wang J (2018) A review of the design and modification of lactoferricins and their derivatives. Biometals. https://doi.org/10.1007/ s10534-018-0086-6

Jiang R, Lonnerdal B (2018) Cloning and characterization of the human lactoferrin receptor gene promoter. Biometals. https://doi.org/10.1007/s10534-018-0080-z

Karav S, German JB, Rouquié C, Le Parc A, Barile D (2017) Studying lactoferrin $N$-glycosylation. Int $\mathrm{J}$ Mol Sci 18:E870. https://doi.org/10.3390/ijms 18040870

Kieckens E, Rybarczyk J, Cox E, Vanrompay D (2018) Antibacterial and immunomodulatory activities of bovine lactoferrin against Escherichia coli O157:H7 infections in cattle. Biometals. https://doi.org/10.1007/s10534-0180082-x
León-Sicairos N, Angulo-Zamudio UA, Vidal JE, López-Torres CA, Bolscher JG, Nazmi K et al (2014) Bactericidal effect of bovine lactoferrin and synthetic peptide lactoferrin chimera in Streptococcus pneumoniae and the decrease in luxS gene expression by lactoferrin. Biometals 27:969-980. https://doi.org/10.1007/s10534-014-9775-y

Mancinelli R, Olivero F, Carpino G, Overi D, Rosa L, Lepanto MS, Cutone A, Franchitto A, Alpini G, Onori P, Valenti P, Gaudio E (2018) Role of lactoferrin and its receptors on biliary epithelium. Biometals. https://doi.org/10.1007/ s10534-018-0094-6

Nakamura K, Kishida T, Ejima A, Tateyama R, Morishita S, Ono T, Murakoshi M, Sugiyama K, Nishino H, Mazda O (2018) Bovine lactoferrin promotes energy expenditure via the cAMP-PKA signaling pathway in human reprogrammed brown adipocytes. Biometals. https://doi.org/10. 1007/s10534-018-0103-9

Parrón JA, Ripollés D, Ramos SJ, Pérez MD, Semen Z, Rubio P, Calvo M, Sánchez L (2018) Antirotaviral potential of lactoferrin from different origin: effect of thermal and high pressure treatments. Biometals. https://doi.org/10.1007/ s10534-018-0088-4

Rosa L, Cutone A, Lepanto MS, Paesano R, Valenti P (2017) Lactoferrin: a natural glycoprotein involved in iron and inflammatory homeostasis. Int J Mol Sci. https://doi.org/ 10.3390/ijms18091985

Rosa L, Cutone A, Lepanto MS, Scotti MJ, Conte MP, Paesano R, Valenti P (2018) Physico-chemical properties influence the functions and efficacy of commercial bovine lactoferrins. Biometals. https://doi.org/10.1007/s10534-018-00928

Valenti P, Antonini G (2005) Lactoferrin: an important host defence against microbial and viral attack. Cell Mol Life Sci 62:2576-2587. https://doi.org/10.1007/s00018-0055372-0

Van der Kraan MI, Nazmi K, van't Hof W, Amerongen AV, Veerman EC, Bolscher JG (2006) Distinct bactericidal activities of bovine lactoferrin peptides LFampin 268-284 and LFampin 265-284: Asp-Leu-Ile makes a difference. Biochem Cell Biol 84:358-362. https://doi.org/10.1139/ o06-042

Vogel HJ (2012) Lactoferrin, a bird's eye view. Biochem Cell Biol 90:233-244. https://doi.org/10.1139/o2012-016

Wakabayashi H, Yamauchi K, Abe F (2018) Quality control of commercial bovine lactoferrin. Biometals. https://doi.org/ 10.1007/s10534-018-0098-2

Ward PP, Piddington CS, Cunningham GA, Zhou X, Wyatt RD, Conneely OM (1995) A system for production of commercial quantities of human lactoferrin: a broad spectrum natural antibiotic. Biotechnology (NY) 13:498-503

Zakharova ET, Sokolov AV, Pavlichenko NN, Kostevich VA, Abdurasulova IN, Chechushkov AV et al (2018) Erythropoietin and Nrf2: key factors in the neuroprotection provided by apo-lactoferrin. Biometals. https://doi.org/10. 1007/s10534-018-0111-9 